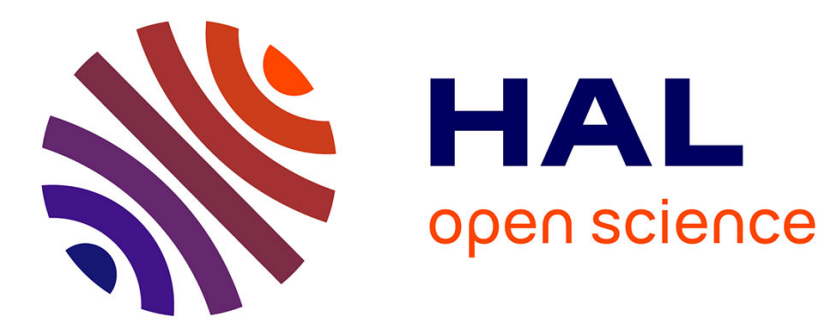

\title{
Method of Research in a We-Paradigm, Lessons on Living Research in Africa
}

Gertjan van Stam

\section{To cite this version:}

Gertjan van Stam. Method of Research in a We-Paradigm, Lessons on Living Research in Africa. 15th International Conference on Social Implications of Computers in Developing Countries (ICT4D), May 2019, Dar es Salaam, Tanzania. pp.72-82, 10.1007/978-3-030-19115-3_7 . hal-02281312

\section{HAL Id: hal-02281312 \\ https://hal.inria.fr/hal-02281312}

Submitted on 9 Sep 2019

HAL is a multi-disciplinary open access archive for the deposit and dissemination of scientific research documents, whether they are published or not. The documents may come from teaching and research institutions in France or abroad, or from public or private research centers.
L'archive ouverte pluridisciplinaire HAL, est destinée au dépôt et à la diffusion de documents scientifiques de niveau recherche, publiés ou non, émanant des établissements d'enseignement et de recherche français ou étrangers, des laboratoires publics ou privés. 


\title{
Method of Research in a We-Paradigm, lessons on Living Research in Africa
}

\author{
Gertjan van Stam ${ }^{1}$ \\ ${ }^{1}$ Macha Works, Zambia \\ gertjan@vanstam.net
}

\begin{abstract}
This paper paints a picture of how a method of research in an African we-paradigm looks like. The paper describes living research, where the researcher is an integral part of a community, being a recipient of communal grace and partaker in, and reporter of, the communal development of embodied knowledge.
\end{abstract}

Keywords: Africa, method of research, we-paradigm, values

\section{Introduction}

Jaco Renken and Richard Heeks [1] argue that the complexities in the social realm succinctly demand diversity in research methods in ICT4D. They posit that the social sciences in general, and sociology in particular, harbour a resource pool of techniques from which researchers can glean approaches that could diversify the theoretical and methodological methods used. This paper presents such a diversification, albeit without adhering to key assumptions that Ramon Grosfoguel [2] shows are considered commonsensical in settings informed by a Euro-Western genealogy. The method of research presented conforms to paradigmatic and value propositions deduced from research at the intersection of technology and society in rural communities in Southern Africa, since the year 2000. The underlying line of inquiry emerged after embodied experiences in the communities in which the author reside(d) show that ICT4D is uncannily Eurocentric. The discourse often fails to recognise local, African ways of knowing and to, subsequently, navigate the clashes of paradigms [3-5].

\section{A fundamental problem: alien framings and foreign methods}

ICT4D research often appear to hold a technocentric gaze set in Eurocentric framings $[6,7]$. Such framing is managed from academic strongholds aligned with Eurocentric worldviews [8-10]. Africans living in Africa have had little chance for participation in constituting discourses [5, 11]. Such framings inculcate coloniality [9, 10, 12, 13]. Dominant philosophy, constructs, theories, methods, and interventions are conceptualised within a logic set in systems of thought aligned with a Eurocentric meaning-making [14-17]. Coloniality obscures the local meaning arrived at through 
the epistemology of those that are experiencing technologies in their daily lives, outside of Western settings [for example, 18, 19].

Methods set the way researchers claim the validity of perceptions and, subsequently, set the base from which theories are proposed. Methods include epistemic filters that frame reality and provide a base of interpretations of what constitutes reality [20]. Western epistemes, however, are mostly foreign to the understanding non-western value orientations [21]; In the poignant words of Alik Shahadah [22]: "You cannot measure an African success with a European ruler."

The South African Cornel du Toit [23] calls to recognise and value subjectivities when assessing scientific integrity. He put this in historical perspective: "[In premodern Africa] the person and what she says is one. This contrasts with the Western notions that the inner world of consciousness and thought is separate from the way the person presents herself in the world." [24] Research in Africa using imported methods undervalues much that is relevant in the local societies [25]. In an effort to provide alternative perspectives and ways to a conversation, I introduce an embedded method of research for unearthing community driven-perspectives, deduced from dynamic and integrative engagement in African communities. Such a method of research, I argue, aligns with the realities in the 'we-paradigm' where an entity exists integral to the whole [5].

\section{The We-Paradigm}

Being full time embedded in African communities since 2000, I noticed incompatibilities in the views of those indigenous to rural African realities and those being introduced to such realities from the outside $[5,11]$. Underlying intricacies I observed through paradigmatic perspectives. In previous work, I conceptualised three distinct paradigms between which my African interlocutors switch voluntarily: the I, we, and it-paradigms [5]. A fundamental difficulty in this paper is to describe a weparadigm in a possibly incommensurable I-paradigmatic setting of a Western-framed academic audience [9].

In the I-paradigm, an individual is a unit of analysis. Gert-Jan Roest [26] argues how this paradigm is dominant in western belief systems; Life is seen as being lived in an age-of-authenticity seeking a self-consciousness that regards the individual (and, therefore, individualism) as the primary agent interacting within society. Roest paints the analogy of likening people to billiard balls, bouncing off each other. In this realm, an individual is urged to seek human power and agency, freedom and fulfilment in self-sufficiency, self-reliance, autonomy, through self-cultivation, and immanent prosperity and security [26]. The individual is the center, placing the self-acting in the world to the exclusion of others.

In the We-paradigm, there is no view of an individual in an existence in that way. Reality, in this worldview, is embedded in a myriad of relationships within a community that contain performers including humans, non-humans and other beings [27]. Community is given primacy where situations arise on who to prioritise between the community and the individual, summed up in: "I am because we are, we are therefore 
I am” [28]. These words link to the idea that human beings cannot live in isolation. Many African cultural settings foreground the primacy of community over the individual from the understanding that humanity depends on community, interconnectedness, conviviality and interdependence [29].

I-paradigm-embedded theories of knowledge and their enactors, I experience daily, have great difficulties to facilitate and recognise the intellectual practices in a we-paradigm. Gayatri Spivak [30] argues that it might be impossible to know what lies outside of one's perception. However, the IFIP 2019 conference seeks to facilitate South-North cooperation and therefore could be sensitive to different ways of knowing. I disagree with Thomas Kuhn [31] who argues it to be impossible to identify a different paradigm, as in previous work I have shown paradigm switching to occur in African communities [5]. Dennis Gioia and Evelyn Pitre [32] argue that insight in different paradigms is possible when we apply transdisciplinary metaperspectives, a technique used by many African authors when they reflect on coloniality in Africa. For instance, Kwame Nkrumah [33], an influential philosopher and political leader in Ghana, in response to his experience with Western theories provided an intellectual framework on social conscience founded in the African values of communal solidarity and presented these in his book consciencism. Other philosophers of note, giving indications of how the epistemic justice could play out in Africa are Kenneth Kaunda, Reuel Khoza, Patrice Lumumba, Munyaradzi Mawere, Lovemore Mbiqi, Julius Nyerere, Francis Nyamnjoh, among many others. From these writers, one gleans that in a we-paradigm knowledge is embodied in an ever becoming social personhood, in a universe of coherence [29, 34]. The Burundian Stanislas Bigirimana [35] shows this embodied knowledge to be a dynamic and integrative knowing. Thus, in the we-paradigm, life unfolds itself as a holistic doing through being, with knowing being part of community engagement, conversation, and representation.

Research in the we-paradigm is to be understood in terms of its meaning and relevance for the communities in which it is performative. Knowledge divorced from a local sense, local knowing or expressed in isolation is void to the local community $[35,36]$. When knowledge is represented in manners foreign to the community [for instance, in textuality, see 36], such declarations of intellectual faculty speaks solely about the researcher's encapsulation in a particular (geo)political agenda [9]. Of course, subsequent interventions ensue uphill battles for their local uptake and might even derail development [for a poignant example from Liberia, see 37]. Except, maybe, during a disaster, it is perverse to talk about local communities and make (research) plans and (research) strategies without authorised representation and engagement of such a community from the very start of deliberations, conceptualisations, planning, and activities. 


\section{Virtues and Values Orientation, examples from Southern Africa}

Many communities in Africa maintain an alliance to so-called indigenous, nonWestern values. These values express themselves in convivial cultures like Ubuntu, espousing communal love [29]. The academic equivalent of such a convivial worldview is a philosophical approach that values positive character traits dubbed virtue epistemology [38, 39]. Such an epistemology necessitates a convivial understanding of local values. Virtue epistemology seeks to share forms of understanding with others in a conscious and intellectual carefulness realising that perception intertwines with matters of attitude, beliefs and morality and knowing benefits from the acknowledgement of a multiplicity of knowledge systems.

Table 1 presents a working-scheme of five African values with some keywords describing their contents. These values do not match with I-paradigmatic propositions as exposed by Roest [26], cited earlier. There is no overlap with neo-liberal ideals of independent markets [cf, 40] or dominant theories of human motivation like those espoused by, for example, Abraham Maslow [41]. Of course, cultures and values are dynamic, shift, and hybridise over time. However, as I argue in my book Reflections [5], this toolbox is productive in view of the conceptualisations regarding philosophies, methods, and theories concerning research in many African communities.

Table 1. A working-scheme of African value orientations [source: 5].

\begin{tabular}{|c|c|c|}
\hline Value & Description & Keywords \\
\hline Ubuntu & Communal love & $\begin{array}{l}\text { African cosmology \& philosophy, morally good } \\
\text { behaviour, conviviality, affirmation, compassion, } \\
\text { solidarity }\end{array}$ \\
\hline Oratio & $\begin{array}{l}\text { Communicating } \\
\text { embodied knowledge }\end{array}$ & $\begin{array}{l}\text { Orality, narrative, knowing, inclusive, collaborative, } \\
\text { conversation, community deposits }\end{array}$ \\
\hline Relatio & $\begin{array}{l}\text { Relational resource } \\
\text { allocation }\end{array}$ & Sharing, needs orientation, relationship building \\
\hline Animatio & $\begin{array}{l}\text { Continuous present } \\
\text { moment }\end{array}$ & $\begin{array}{l}\text { Here-and-now, constituting history, emerging future, } \\
\text { connectedness, rhythm, belonging, humaneness }\end{array}$ \\
\hline Dominio & Seeking maturity & Reconciliation, continuity, covenant \\
\hline
\end{tabular}

\section{$5 \quad$ Living Research}

The philosophical grounding of living research in Africa relies, of course, on African philosophy. Munyaradzi Mawere and Tapuwa Mubaya [42] describe African philosophy as meaning "the contextualised critical thinking, articulation of ideas, and attempts to seek solutions to problematic situations by Africans.” African philosophy, in the sense of Mawere and Mubaya, presupposes plurality and the participation of all 
in communiversity (ibid, 46). The articulations of African philosophies and related ontologies, epistemologies, ethics, and metaphysics are relatively recent as selfexploration of African thought by African researchers was actively suppressed till the end of settler colonisation in the 1960s and 70s. The initial propositions about such a philosophy, of course, are not settled and leave much room for debate, exploration and contributions $[43,44]$.

The outset of living research is to push the method of research beyond 'the usual suspects' where normative epistemologies dominate, silence, objectivise, and normalise [35, 45, 46]. Beyond what is pre-set in the researchers' Eurocentric academic vocabulary, the approach to research seeks sensitisation and training to discover consciousness from within the locally active paradigm. The method of research seeks priority for attaining an appreciation of the local understanding of local expressions of phenomena, in local manners. Living research depends upon one's inclusion and living-the-life, being part of the structures, practices, hopes, aspirations and fears in a community [47].

Focus on community is pivotal in a decolonised research [12]. Both the source and clients of research are embedded in communities. Any interaction involves communications within communities and derivates are subject to communal processes. In the case of Macha Works in Zambia [48], I distinguish seven steps that facilitated the living research in that community [12]:

1) the community prioritises research and asks for its execution [for example, 49]

2) community members introduce research to the relevant authorities [for instance, in the House of Chiefs in Zambia, 50],

3) development of research concepts, proposals and execution processes take place within and with the community in the methods of co-creation [5]

4) any development and any communication is instantly interacted upon in the (geographical) location of the communities concerned [36, 51]

5) community members disclose embodied knowledge first and continue to be preferred presenters on research progress (for example, Macha's Fred Mweetwa at SXSW, USA, in 2014, and the Community Networks Summit, South Africa, and African Internet Forum, Sudan, in 2018)

6) any presentation or write-up concerning the research is co-developed, discussed and shown in the community first, after which representation could be granted for its dissemination outside of the community [52]

7) the community has veto rights to cancel or stall external propagation [for example, 53]

In living research, the researcher is an integral member of the community and visible as such, being a participant in interactions that affect embodied knowledge. The researcher, in my experience, mostly receives culturally-framed, implicit invitations to contribute to the dynamic and integrative processes that constitute communal knowing and, subsequently receives explicit requests to represent theoretical understandings that interact with broader social phenomena or extant theories. 
The communal inclusion of the researcher in a community is an act of communal grace. Such grace is common in the sociology of ubuntu where "everyone exists by the grace of the other" [cited in, 5, 54]. Grace unsettles oriental, imperial, and colonial frames. Living research, therefore, acts within the parameters of the grace received from a community based upon a confession of character [5]. Such grace is remarkable as it is not necessary for a community to enable a researcher to be part of communal life.

The validity of living research links in with the means of entrance, the introduction. Also, such research is subject to local authority and thus reporting to local governing bodies. In this, being a researcher and doing research is not a removed activity nor confined to the academic art of writing of papers; It is a vocation, an identity [cf, 45]. Any breath and action in a community has moral and scientific consequences. Such an outlook surpasses artificial dichotomies, for instance, in being and doing by blending role performance, authority, and observatory virtue in continuous communal learning and growing in knowing and becoming [55]. Such a stand might very well need measures of faith as to the materiality of the learnings to be acquired and a hope that it is possible to know.

Communities have distinctive authorities over what happens at the sites of enquiry. Gaining the necessary trust through tests of character and consistency of interactions and, subsequently, receiving the invitation to become an embodied part of the collective knowledge base takes many interactions in every facet of ones living [47]. Depending on the context, for instance, it took me at least five years of active waiting to be allowed access to local ways of knowing in various communities in Zimbabwe and Zambia [5].

Living research and its exploits are about understanding in relation with others, through covenants between people [56]. Through such covenants, the community is both sovereign and bound while remaining empowered as what and how to reveal whenever and however the community wishes to act and position any proceeds. Anything outside of such a covenant, for instance, appropriated data and uncollaborative write-ups, the community can consider manipulative, embezzlement, and/or projection [cf, 57]; "If the end product of foreign academic research is a takeaway text written in academic English, then the foreign academic appropriates local culture for private and foreign profit, leaving the local community objectified and exploited.” [36]

The primary drive for living research is to get to know people and practices embedded in conversation in communities. In practice, this involves a never-ending and continuous interaction with anyone in any setting, 24 hours a day, seven days a week, 365 days a year. Only death or expulsion can end such a connection. Research, thus, involves transparency and intellectual commitment in any encounter where one lives and works and where one meets. The researcher relies upon an outward-looking posture and attitude, with continuous attention and interest in those around: actively getting to know interests, believes, dreams, and fears, in a metaphysical world. 


\section{Discussion}

Michael Burawoy [45], among others, elaborates on the existence of various sciences. He positions one side focusing on positive sciences that rely on rationality, logic, and facts (which he shows, convincingly, to be unattainable). The other side, Burawoy positions reflexive sciences involving a presence and agency of the person looking. Living research is a paradigmatic response to the fundamental questioning of methods of research and how they relate with power. Nokuthula Hlabangane [9] provides insights into how methodologies issue from and adhere to a particular knowledge system: Eurocentric research issues from the I-paradigm. In this manner, for instance, living research differentiates from various forms of group-/collective-/networkoriented ICT4D research, especially where the latter thrives on aspects of individualism, seeks delineations or bifurcations, aims for textualisation, or insists on categorisations set outside of the community. With its orientation towards dynamic and integrative/embodied knowledge and conviviality, living research is ever emerging and changing and can only give an indication of temporary status. Also, living research differentiates with autoethnography, as the latter links in with the researcher's individual self, as in a Descartesian conversation with oneself considering one's own nature. Living research, however, seeks the local epistemology as the frame of reference, seeking to align with a communal-self, inclusive of meaning contained in congregating beings and non-beings, for instance in Ubuntu [29].

The outcomes of research in the I-paradigm appear quite incommensurably with research in the we-paradigm. The I-paradigm is perpetuating as texts, written out of context, becoming pretext in subsequent research. Proceedings in the we-paradigm cannot be judged from the I-paradigm. Often, knowledge and judgement from the Iparadigm are irrelevant and a nuisance to an African community and their knowledge keepers. I experienced that such knowledge and judgement could generate damage in the form of the arrival of unsustainable electronic artefacts [58], broken relationships because of exclusion criteria, or a general feeling of inferiority or exploitation [36, 59, 60].

Being privy to, and included in, local ways of knowing involves moral obligations for constant communal reflection on any aspect of the research. Power issues are a prime subject for discussion as are matters of means of colonisation hidden in the practice of research (example: vendor lock-in). Other items are how to deal with the bifurcating presence of individualism (a particular trait and ideal in the I-paradigm) or questions about why perceived deductions were unavailable and why they should become embodied (example: the issue of taboos).

Living research involves periods of imagination. As Kahneman [61] shows, the human mind starts with assumptions and reflects information against those assumptions. In living research, the community challenges the pre-set assumptions and engages to reconcile history and contemporary contributions into embodied knowledge [34]. For this, the researcher has to assess evidence and 'knowledge' with a reflective mind's eye, recognising what Francis Nyamnjoh [62] called the conviviality of knowledges, celebrating incompleteness, and prioritising fluidity against fixedness of prescriptions, standardisations or routines. 
Communal processes that sustain knowing involves the oratory art of articulation [36]. Co-production, in the communal setting, is the construction of deductions in manners that are recognised by the local community, the wider community, and the world (in that sequence). This articulation is not necessarily in writing (first) but involves a whole range of ways in which to express thought. The result, an emerging reconstruction, is subsequently embedded and embodied in the researcher as part of a local system of knowing, ongoing conversation, and, when expanding beyond what is known so-far, on improvisation [63].

\section{Conclusion}

This paper calls out at the Eurocentrism in ICT4D research by providing insights into a method of research embedded in the we-paradigm. The paper has drawn on extensive experience and African scholars to show the value of African scholarship to discuss phenomena in words and language set in context and associated with African place and positionality. Through living research, the paper offers directions forward that can inform method of research in ICT4D, although it appears far removed from practices as trained and executed in Western epistemology-based research practices. In daily practice, living research is all-consuming, with the researchers entirely being engaged with the lived-life of the research in community.

Living research resonates with African contexts and worldviews. Of course, it needs stamina, to continue even when confronted with discomforting truths, confronting opinions, cognitive dissonance or even emotional dissonance appear. The presented paradigmatic approach, its practice, and a supporting set of communal values, I hope, can be helpful to both native African researchers and those visiting from foreign contexts.

\section{Acknowledgement}

I acknowledge the communal grace of communities throughout Africa that allowed to unearth the principles presented in this paper. Also, I acknowledge the constructive criticism and suggestions of the (unfortunately) unnamed reviewers of the earlier version of this paper.

\section{References}

1. Renken, J., Heeks, R.: Social network analysis and ICT4D research: Principles, relevance, and practice. The Electronic Journal of Information Systems in Developing Countries 84: e12036 (2018).

2. Grosfoguel, R.: The Structure of Knowledge in Westernized Universities: Epistemic Racism / Sexism and the Four Genocides/Epistemicides of the Long 16th Century. Human Architecture: Journal of the Sociology of Self-Knowledge 11, 73-90 (2013).

3. van Stam, G.: Orientalism Embedded in Foreign Narratives of Technology for Development. In: Proceedings of $1^{\text {st }}$ Institute of Lifelong Learning and Development Studies International Research Conference, Chinhoyi University of Technology, 2-5 August 2016, 
Chinhoyi, Zimbabwe (2016).

4. Mawere, M., van Stam, G.: Paradigm Clash, Imperial Methodological Epistemologies and Development in Africa: Observations from rural Zimbabwe and Zambia. In: Mawere, $\mathrm{M}$. Mwanaka, T. (eds.) Development, Governance, and Democracy: A Search for Sustainable Democracy and Development in Africa, pp. 193-211. Langaa RPCIG, Bamenda (2015).

5. van Stam, G.: Reflections: a narrative on displacement of technology and meaning in an African place. Gertjan van Stam, Harare, Masvingo, Macha, Tilburg (2017).

6. Toyama, K.: Heresy: Rescuing Social Change from the Cult of Technology. Kindle. PublicAffairs, New York (2015).

7. Unwin, T.: Reclaiming Information and Communication Technologies for Development. Oxford University Press, Oxford (2017).

8. Nyamnjoh, F. : \#RHODESMUSTFALL. Nibbling at Resilient Colonialism in South Africa. Langaa RPCIG, Bamenda (2016).

9. Hlabangane, N.: Can a Methodology Subvert the Logics of its Principal? Decolonial Meditations. Perspectives on Science 26, 658-693 (2018).

10. Nyamnjoh, F.: "Potted Plants in Greenhouses": A Critical Reflection on the Resilience of Colonial Education in Africa. Journal of Asian and African Studies 47, 129-154 (2012).

11. van Stam, G.: Is Technology the Solution to the World's Major Social Challenges? In: IEEE Global Humanitarian Technology Conference (GHTC 2012), 21-24 Oct 2012, Seattle, WA, USA (2012).

12. van Stam, G.: Decolonising Science: Switching the Paradigm to 'Community.' In: Invited Address, University of the Western Cape, Bellville, Cape Town, South Africa, 6 November 2017 (2017).

13. Dourish, P. Mainwaring, S.: Ubicomp’s Colonial Impulse. In: UbiComp’12, 5-8 Sep 2012, Pittsburgh, USA (2012).

14. Ndlovu-Gatsheni, S.: Empire, Global Coloniality and African Subjectivity. Berghahn Books, New York (2013).

15. Nhemachena, A.: Animism, Coloniality and Humanism: Reversing Empire's Framing of Africa. In: Mawere, M., Nhemachena, A. (eds.) Theory, Knowledge, Development and Politics: What Role for the Academy in the Sustainability of Africa?, pp. 13-54. Langaa RPCIG, Bamenda (2016).

16. Grosfoguel, R.: Transmodernity, border thinking, and global coloniality. Humandee, 1-32 (2008).

17. Maldonado-Torres, N.: On the Coloniality of Being. Contributions to the development of a concept. Cultural Studies 21, 240-270 (2007).

18. van Stam, G. Framing “ICT Access in Rural Africa.” In: $11^{\text {th }}$ Prato CIRN Conference, 1315 Oct 2014, Prato, Italy (2014).

19. van Greunen, D. van Stam, G.: Review of an African Rural Internet Network and related Academic Interventions. The Journal of Community Informatics 10 (2014).

20. Heidegger, M.: Being and Time. State University of New York Press, Albany (1996).

21. Mawere, M., Nhemachena, A.: "Blackness," "Whiteness" and the Euro-American Socioeconomic and Political Exploitation and Theorisation of Africa: An Introduction. In: Theory, Knowledge, Development and Politics: What Role for the Academy in the Sustainability of Africa?, pp. 1-12. Bamenda: Langaa RPCIG (2016).

22. Shahadah, O.: Agency and Africans. Africanholocaust.net (2012).

23. du Toit, C.: The restoration of subjectivity in science, rationality and knowledge systems as a precondition for scientific integrity Introduction. Journal for Interdisciplinary Research on Religion and Science, 163-185 (2007).

24. du Toit, C.: African challenges. Unfolding identities. Unisa Press, Pretoria (2009).

25. Mignolo, W.: Epistemic Disobedience, Independent Thought and Decolonial Freedom. Theory, Culture \& Society 26, 159-181 (2009).

26. Roest, G.: The Gospel in the Western context. A missiological reading of Christology in 
dialogue with Hendrikus Berkhof and Colin Gunton. Vrije Universiteit, Amsterdam (2016).

27. Mawere, M.: Humans, Other Beings and the Environment. Harurwa (Edible Stinkbugs) and Environmental Conservation in Southeastern Zimbabwe. Cambridge Scholars Publishing, Newcastle upon Tyne (2015).

28. Mbiti, J.: African Religions and Philosophy. Heinemann, London (1976).

29. Mawere, M. van Stam, G.: Ubuntu/Unhu as Communal Love: Critical Reflections on the Sociology of Ubuntu and Communal Life in sub-Saharan Africa. In: Mawere, M., Marongwe, N. (eds.) Violence, Politics and Conflict Management in Africa: Envisioning Transformation, Peace and Unity in the Twenty-First Century, pp. 287-304. Langaa RPCIG, Bamenda (2016).

30. Spivak, G.: Can the Subaltern Speak? In: Nelson, C. Grossberg, L. (eds) Marxism and the Interpretation of Culture, pp. 66-111. Champaign: University of Illinois Press (1988).

31. Kuhn, T.: The Structure of Scientific Revolutions. Second edition. The University of Chicago Press, Chicago (1970).

32. Gioia, D. Pitre, E.: Multiparadigm Perspectives on Theory Building. Academy of Management Review 15, 584-602 (1990).

33. Nkrumah, K.: Consciencism. Monthly Review Press, New York (1964).

34. Mawere, M. van Stam, G.: Oratio: A Framing of Knowledge in the Context of Technology and Academia. In: Mawere, M., Mubaya, T. (eds.) African Studies in the Academy. The Cornucopia of Theory, Praxis and Transformation in Africa?, pp. 251-264. Langaa RPCIG, Bamenda (2017).

35. Bigirimana, S.: Beyond the thinking and doing dichotomy: integrating individual and institutional rationality. Kybernetes 46, 1597-1610 (2017).

36. van Stam, G.: Information and Knowledge Transfer in the rural community of Macha, Zambia. The Journal of Community Informatics 9 (2013).

37. van Reisen, M. International cooperation in the digital era. In: Inaugural lecture, Computing for Society, 10 March 2017. Leiden University, Leiden (2017).

38. Chinn, C., Buckland, L., Samarapungavan, A.: Expanding the Dimensions of Epistemic Cognition: Arguments From Philosophy. Educational Psychologist 46, 141-167 (2011).

39. Flyvbjerg, B.: Social science that matters. Foresight Europe, 38-42 (2006).

40. Sheneberger, K. van Stam, G.: Relatio: An Examination of the Relational Dimension of Resource Allocation. Economics and Finance Review 1, 26-33 (2011).

41. Mawere, M. Mubaya, T., van Reisen, M., van Stam, G.: Maslow’s Theory of Human Motivation and its Deep Roots in Individualism: Interrogating Maslow's Applicability in Africa. In: Mawere, M., Nhemachena, A. (eds.) Theory, Knowledge, Development and Politics: What Role for the Academy in the Sustainability of Africa?, pp. 55-72. Langaa RPCIG, Bamenda (2016).

42. Mawere, M., Mubaya, T.: African Philosophy and Thought Systems. A Search for a Culture and Philosophy of Belonging. Langaa RPCIG, Bamenda (2016).

43. Hountondji, P.: African Philosophy: Myth and Reality. Second editions. Indiana University Press, Bloomington and Indianapolis (1996).

44. Hallen, B.: A Short History of African Philosophy. Indiana University Press, Bloomington (2002).

45. Burawoy, M.: The Extended Case Method. University of California Press, Berkeley and Los Angeles (2009).

46. van Stam, G.: An Introspective, Strategic Narrative on Living Research on Technology and Community in an African place. In: Proceedings of Strategic Narratives of Technology and Africa, 1-2 Sep 2017, Funchal, Madeira (2017).

47. Bets, J., van Stam, G., Voorhoeve, A.: Modeling and Practise of Integral Development in Rural Zambia: Case Macha. In: Jonas, K., Rai, I., Tchuente, M. (eds.) 119: E-Infrastructures and E-Services on Developing Countries, $4^{\text {th }}$ International ICST Conference, 
Africomm 2012, Yaounde, Cameroon, November 12-14, 2012, Revised Selected Papers, pp. 211-220. Springer, Berlin, Heidelberg (2013).

48. Mweetwa, F., van Stam, G.: Community Engagement in Community Networks in Rural Zambia: The Case of Macha Works. In: Global Information Society Watch 2018. Community Networks, 256-259. Association for Progressive Communications (APC) and International Development Research Centre (IDRC) (2018).

49. Chief Chikanta, Mweetwa, F.: The Need for Information and Communications Technologies. LinkNet, Macha (2007).

50. Mweetwa, F., Mweemba, G., van Stam, G.: A Vision for Information and Communications Technology (ICT) in Rural Areas. In: House of Chiefs, Lusaka (2009).

51. Kroczek, A., Mweetwa, F., van Stam, G.: Stakeholder Theory and ICT in rural Macha, Zambia. In: Proceedings of $5^{\text {th }}$ Annual International Conference on ICT for Africa (ICT4Africa), 20-23 Feb 2013, Harare, Zimbabwe (2013).

52. van Stam, G.: Thought Leadership in e-Governance, e-Infrastructure, and e-Business in Africa. In: Proceedings of the Fifth International IEEE EAI Conference on e Infrastructure and e Services for Developing Countries (Africomm 2013), 25-27 November 2013, Blantyre, Malawi. (2013).

53. van Stam, G.: Public PhD Defense. In: Public Defense at Tilburg University, 15 Sep 2017 (2017).

54. van Stam, G.: Ubuntu, Peace, and Women: Without a Mother, there is no Home. In: van Reisen, M. (ed.) Women's Leadership in Peace-Building: Conflict, Community and Care, pp. 37-54. Africa World Press, Trenton (2014).

55. Ellingson, L., Ellis, C.: Autoethnography as Constructionist Project. In: Holstein, J., Gubrium, F. (eds.) Handbook of constructionist research, pp. 445-465. Guilford, New York (2008).

56. Winks, B.: A covenant of compassion: African humanism and the rights of solidarity in the African Charter on Human and Peoples' Rights. African Human Rights Law Journal 11, 447-464 (2011).

57. The Lancet Global Health: Closing the door on parachutes and parasites. The Lancet Global Health 6, e593 (2018).

58. Johnson, D., van Stam, G.: The Shortcomings of Globalised Internet Technology in Southern Africa. In: Proceedings of Africomm 2016, 6-7 Dec 2016, Ouagadougou, Burkina Faso (2016).

59. Tuck, E.: Suspending Damages. Harvard Educational Review 79, 409-428 (2009).

60. van Stam, G.: The Coming-of-Age of Super-Colonialism. In: Mawere, M. and Mubaya, T. (eds.) African Studies in the Academy. The Cornucopia of Theory, Praxis and Transformation in Africa?, pp. 13-40. Langaa RPCIG, Bamenda (2017).

61. Kahneman, D.: Thinking, Fast and Slow. Kindle. Penguin Books, London (2011).

62. Nyamnjoh, F.: Drinking from the Cosmic Gourd: How Amos Tutuola Can Change Our Minds. Langaa RPCIG, Bamenda (2017).

63. Mawere, M., van Stam, G.: African Engineering and the Quest for Sustainable Development: Levelling the Ground for all Players. In: Mawere, M., Nhemachena, A. (eds.) Theory, Knowledge, Development and Politics: What Role for the Academy in the Sustainability of Africa?, pp. 189-206. Langaa RPCIG, Bamenda (2016). 